\title{
Hubungan Perilaku Orang Tua Dalam Pemilihan Makanan Bergizi Dengan Status Gizi Pada Anak Usia Pra Sekolah
}

\author{
Al Syafarinoo ${ }^{a}$, Lilla Maria ${ }^{a}$, Rahmawati Maulidiaa

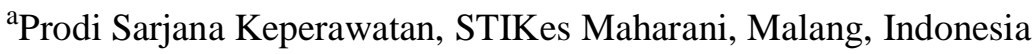

Email Korespondensi: syafari.asn@gmail.com

\begin{abstract}
Introduction: Parents act has an important role in fulfilling the children's food needs to support the process of their growth and nutritional status. This research objective is to find out correlation between the parents capability in selecting nutritious food and nutritional status of pre-school age children in TK ABA 06 Mergosono Kedungkandang, Malang. Method: The design of this research is correlation with cross sectional approach. The research populations were 70 people. The sample were determined by using purposive sampling who were 60 respondents. The technique of collecting data was questionnaires. The data were analyzed by using Spearmen Rank Test and SPSS. Results: The research results proved that most of the respondents, 39 (65.0\%) parents, had sufficient capability in selecting nutritious foods for the pre-school age children and almost entire respondents, 52 (86.7\%) pre school age children, had good nutritional status. Test result of Spearmen Rank Test obtained p-value $=(0.000)<(0.05)$. Conclusion: It can be concluded that there is correlation between parents'capability in selecting nutritious food and nutritional status in pre-school age children in TK ABA 06 Mergosono Kedungkandang, Malang. From the result of the research, it is stated that in improving the nutritional status of pre-school aged children needs a good capability of the parents in selecting nutritious food.
\end{abstract}

Keywords: Behavior, Nutritional Food, Nutritional Status Parents, Preschool

\begin{abstract}
Abstrak
Pendahuluan: Perilaku orang tua berperan penting dalam mencukupi kebutuhan makanan anak untuk mendukung proses tumbuh kembang dan status gizinya. Tujuan penelitian untuk mengetahui hubungan perilaku orang tua dalam pemilihan makanan bergizi dengan status gizi pada anak usia pra sekolah di TK ABA 06 Mergosono, Kendungkandang, Kota Malang. Metode: Desain penelitian mengunakan korelasi dengan pendekatan cross sectional. Populasi penelitian sebanyak 70 orang, penentuan menggunakan purposive sampling sehingga sampel penelitian sebanyak 60 responden. Teknik pengumpulan data menggunakan kuesioner. Metode analisa data yang di gunakan yaitu uji spearmen rank menggunakan SPSS. Hasil: Penelitian membuktikan sebagian besar $39(65,0 \%)$ orang tua memiliki perilaku cukup dalam pemilihan makanan bergizi pada anak usia pra sekolah dan hampir seluruhnya $52(86,7 \%)$ anak usia pra sekolah memiliki status gizi baik. Hasil ujispearmen rank didapatkan nilai $p=(0,000)<(0,05)$. Kesimpulan Disimpulkan bahwa ada hubungan perilaku orang tua dalam pemilihan makanan bergizi dengan status gizi pada anak usia pra sekolah di TK ABA 06 Mergosono, Kendungkandang, Kota Malang. Berdasarkan hasil penelitian untuk meningkatkan status
\end{abstract}

Syafarinoo, A., dkk., Hubungan Perilaku Orang Tua dengan Status Gizi 
gizi anak usia pra sekolah maka perlu adanya perilaku orang tua yang baik dalam pemilihan makanan bergizi.

Kata Kunci: Makanan Bergizi, Status Gizi, Perilaku, Pra Sekolah, Orang Tua

\section{PENDAHULUAN}

Undang-undang

tentang

perlindungan anak no 23 tahun 2002 menjelaskan bahwa anak adalah seseorang yang masih belum berusia 18 tahun (Hidayat, 2005). menjelaskan bahwa anak merupakan individu yang berada pada suatu rentang perubahan perkembangan yang dimulai dari baiyi hingga remaja. Pertumbuhan dan perkembangan anak berlangsung secepat dan di pengaruhi banyak banyak faktor. Salah satu faktor yang mengandung proses tumbuh kembang anak yang optimal yaitu zat gizi yang cukup dari makanan sehari-hari (Adriani \& Wirjatmadi 2012).

Status gizi merupakan salah satu faktor yang berpengaruh pada kualitas sumber daya manusia (SDM), terutama yang terkait dengan kecerdasan, produktifitas dan kreatifitas. Salah satu periode penting dalam tumbuh kembang anak adalah masa anak usia pra sekolah yaitu usia 4 sampai 6 tahun. Pada masa tersebut anak perlu memperoleh asupan gizi dari makanan sehari-hari dalam jumlah yang tepat dan kualitas yang baik (Adriani, Wirjatmadi, 2012).

Gizi seorang anak di pengaruhi oleh faktor langsung dan tidak langsung. Faktor penyebab secara langsungyaitu bisa dari makanan, dan penyakit infeksi yang di dederita oleh seorang anak. Gizi kurang tidak hanya di sebabkan makanan saja tetapi juga di pengaruhi oleh faktor penyakit infeksi seperti gangguan nafsu makan, pencernaan dan penyerapan makanan di dalam tubuh. Faktor tidak langsung yaitu ketahan makanan pada keluarga, pola asuh, perawatan kesehatan dan lingkuang kurang memadai . dari faktor tidak langsung saling berkaitan dengan pendidikan, pengetahuan, pendapatan, dan keterampilan orang tua (Adisasmito, 2010).

Masalah gizi pada anak dapat disebabkan oleh beberapa faktor seperti makanan yang tidak seimbang dan penyakit infeksi, ketahanan pangan di keluarga yang tidak memadai seperti kemampuan keluarga yang kurang untuk memenuhi kebutuhan pangan seluruh anggota keluargannya, baik jumlah maupun gizinya. Masalah gizi juga disebabkan oleh kemampuan keluarga yang kurang untuk menyediakan waktu, perhatian dan dukungan terhadap anak agar dapat tumbuh kembang dengan sebaik-baiknyabaik secara mental, maupun sosial dan fisik Badan Perencanaan Pembangunan Nasional, (2010). Penelitian yang terkait dengan status gizi anak pernah dilakukan terutama berhubungan dengan faktor sosial ekonomi, lingkungan, infeksi, pekerjaan orang tua, dan pengetahuan orang tua tentang masalah gizi, tetapi tetapi penelitian tentang status gizi yang dihubungan dengan perilaku orang tua dalam memberikan suatu asumsi makanan pada anak pra sekolah masih terbatas terutama yang dilakun di Indonesia (Ni Luh Agustini Purnama, Lely Lusmilasari, 2015).

Perilaku yang sering dilakuakan orang tua adalah pemberian contoh makanan yang sehat. Lima tahun pertama anak merupaka periode perilaku makan yang penting sebagai dasar pola makan yang akan datang. Dalam hal ini peran orang tua sangatlah penting dalam pengalaman makan karena pengalaman ini berkaitan dengan perilaku anak dan status berat badan. Rata-rata $\mathrm{d}=$ skor orang tua dalam melakukan pembatasan untuk mengontrol berat badan sebesar 1,9 yaitu pada rentang tindakan pernah sampai jarang. Hal ini disebabkan sebagian besar anak pada kondisi status gizi normal dan 
hanya $11,7 \%$ yang gemuk sehingga orang tua tidak melakukan pembatasan untuk mengontrol berat badan anaknya (Ni Luh Agustini Purnama, Lely Lusmilasari, 2015).

Perilaku pemberian makanan yang dilakukan sangat berperan penting dalam pemenuhan suatu kebutuhan nutrisi bagi tumbuh kembang anak. Beberapa penelitian membahas terkait masalah perilaku orang tua dalam memberikan makan pada anak misalnya makanan yang manis sebagai hadia untuk mengontrol anak dan tidak ada kontrol dalam pemilihan makanan anak .orang tua tidak menentukan makanan yang sebaiknya dimakan anaknya, tetapi cenderung menuruti keinginan anaknya dan memaksa anak untuk tetap makan meskipun anak sudah tidak mau (Ni Luh Agustini Purnama, Lely Lusmilasari, 2015).

Perilaku orang tua dalam mengontrol perilaku makan anak berhubungan siknifikan secara positif dengan status gizi anak 2-5 tahun pada kondisi anak kurus, normal ataupun gemuk. Semakin sering orang tua membiarkan anaknya mengontrol atau memilih dan asupan makanan sendiri maka semakin tinggi status gizi anak. Kontrol makanan anak merupakan praktik pemberian makanan yang negatif karena orang tua membiarkan anak mengontrol sendiri memilih dan asupan makanannya yang mempengaruhi seberapa banyak makan makanan yang sehat. Kemampuan mengontrol perilaku anak usia 2-5 tahun lebih berkembang sehingga anak memiliki kebebasan untuk memilih makanan yang diinginkannya. Saat orang tua mengizinkan anak memilih dan makanan yang diinginkan maka anak memiliki kebebasan untuk memilih makanan yang yang disukai sehingga asupan makanan juga sangat kuat apabila didukung dengan berbagai pilihan makanan dengan zat gizi yang seimbang sesuai dengan kebutuhan anak. Kebebasan berlebihan dari orang tua juga dapat menyebabkan perilaku makanan anak yang tidak sehat sehingga asupan makanan berlebihan dan tidak seimbang dan pada akhirnya anak menjadi gemuk (Ni Luh Agustini Purnama, Lely Lusmilasari, 2015).

hadia $\begin{gathered}\text { Menggunakan } \\ \text { berhubungan }\end{gathered}$ signifikan $\begin{array}{r}\text { sebagai } \\ \text { secara }\end{array}$ negatif dengan status gizi anak pada status gizi anak sangat kurus hingga gemuk. Hal ini berarti bahwa semakin sering orang tua menggunakan makanan sebagai hadiah maka semakin rendah status gizi anak $\mathrm{Ni}$ Luh Agustini Purnama (Lely Lusmilasari, 2015). (Menurut Shan, 2010). BejingChina. Ditemukan bahwa perilaku orang tua dalam pemenuhan status gizi anak mempunyai pengaruh penting terhadap status berat badan anaknya. Selain itu (Shan, 2010). Menambahkan bahwa pengetahuan mengenai gizi anak sangat diperlukan untuk membentuk perilaku yang baik.

Riset Kesehatan Dasar Nasional (2018), menyatakan prevalensi anak usia pra sekolah Salah satu masalah kesehatan dan sosial yang di hadapi Indonesia adalah rendahnya status gizi masyarakat. Dan menurut Riskesdes (2018) Proporsi status gizi sangat pendek turun dari 37,2\% (Riskesdes 2013) menjadi 30,8\%. Begitu juga proporsi status gizi buruk dan gizi kurang turun dari 19,6\% menjadi $17,7 \%$. Riskesdes (2018) Menurut (Adriani \& Wirjatmadi, 2012). Dalam proses tumbuh kembang di tentukan oleh makanan yang di makan sehari-hari, dimana jumlah makanan yang di berikan anak berangsur sesuai dengan bertambahnya kebutuhan anak akan berbagai asupan gizi.

Selain itu masyarakat belum menyadari anak pendek merupakan suatu masalah, karena anak pendek di masyarakat terlihat sebagai anak-anak dengan aktivitas yang normal, tidak seperti anak kurus yang harus segera ditanggulangi. Demikian pula halnya gizi ibu waktu hamil, masyarakat belum 
menyadari pentingnya gizi selama kehamilan berkontribusi terhadap keadaan gizi bayi yang akan dilahirkannya kelak (Unicef Indonesia, 2013).

Prevalensi kejadian Stunting di Indonesia berda pada kelompok high prevalence, sama halya dengan Negara Kamboja dan Myanmar (Bloem et al, 2013). Dari 556 juta anak si Negara berkembang 178 juta anak (32\%) bertubuh pendek dari 19 juta anak sangat kurus $(<-$ 3SD) dan 3,5 juta anak meninggal setiap tahun Black et al, 2008; (Cobham, 2013).

Berdasarkan studi pendahuluan yang dilakukan pada bulan Oktober 2018 di TK ABA 06 Margosono, Kandungkandang, Kota Malang, hasil wawancara dengan 7 orang tua siswa dalam pemilihan makanan bagi anak, didapatkan 2 ibu dalam pemilihan makanan bagi anaknya hanya memberikan roti dan susu, hanya sesekali memberikan nasi, di karenakan anaknya susah makan nasi saat pagi, dan anaknya lebih sering makan jajanan di warung. Sedangkan 5 diantarannya mengatakan bahwa pemilihan makanan bagi anaknya sama dengan makanan keluarga dan yang terpenting anaknya merasa kenyang.

Berdasarkan uraian data di atas, masih banyak di temukan asupan nutrisi dan masalah gizi kurang pada anak usia pra sekolah, membuat penulis tertarik untuk mengetahui dan meneliti jelas masalah hubungan perilaku orang tua dalam pemilihan makanan bergizi dengan status gizi pada anak usia pra sekolah.

\section{METODE}

Penelitian ini menggunakan desain korelatif dengan pendekatan cross sectional yaitu pengambilan data penelitian sekali saja pada waktu pengamatan yang sama. Penelitian ini bertujuan untuk mencari hubungan perilaku orang tua dalam pemilihan makanan bergizi dengan status gizi pada anak usia pra sekolah. Populasi dalam penelitian ini adalah semua orang tua dan anak usia pra sekolah di TK ABA 06 Mergosono, Kandungkandang, Kota Malang. Sempel dalam penelitian ini adalah 60 orang tua dan anak usia pra sekolah di TK ABA 06 Mergosono, Kandungkandang, Kota Malang. Teknik sampling yang digunakan dalam penelitian ini adalah jenis purposive sampling. Instrument yang digunakan dalam penelitian ini menggunakan lembar observasi pengukuran tinggi badan (TB) dan berat badan (BB) yang disesuaikan dengan tabel Antropometri.

\section{HASIL}

Tabel 1.Distribusi Frekuensi Perilaku Orang Tua Dalam Pemilihan Makanan Bergizi Pada Anak Usia Pra Sekolah di TK ABA 06 Mergosono, Kendungkandang, Kota Malang

\begin{tabular}{ccc}
\hline Perilaku Orang Tua & Frekuensi & Persentase (\%) \\
\hline Baik & 18 & 30,0 \\
Cukup & 39 & 65,0 \\
Kurang & 3 & 5,0 \\
\hline Total & 60 & 100 \\
\hline
\end{tabular}

Berdasarkan Tabel 1. diketahui sebagian besar $39(65,0 \%)$ orang tua memiliki perilaku cukup dalam pemilihan makanan bergizi pada anak usia pra sekolah di TK ABA 06 Mergosono Kota Malang, didapatkan juga kurang dari separuh $18(30,0 \%)$ orang tua memiliki perilaku baik dan sebagian kecil $3(5,0 \%)$ orang tua memiliki perilaku kurang.

Tabel 2.Distribusi Frekuensi Status Gizi Pada Anak Usia Pra Sekolah di TK ABA 06 Mergosono, Kendungkandang, Kota Malang

\begin{tabular}{ccc}
\hline Status Gizi Anak & Frekuensi & Persentase (\%) \\
\hline Gizi kurang & 4 & 6,7 \\
Gizi baik & 52 & 86,7 \\
Gizi lebih & 4 & 6,7 \\
\hline
\end{tabular}


100

Berdasarkan Tabel 2. diketahui hampir seluruhnya $52(86,7 \%)$ anak usia pra sekolah memiliki status gizi baik di TK ABA 06 Mergosono, Kendungkandang, Kota Malang, didapatkan juga sebagian kecil $4(6,7 \%)$ anak memiliki status gizi lebih dan sebagian kecil $4(6,7 \%)$ anak memiliki status gizi kurang.

Tabel 3. Tabulasi Silang Hubungan Perilaku Orang Tua Dalam Pemilihan Makanan Bergizi Dengan Status Gizi Pada Anak Usia Pra Sekolah di TK ABA 06 Mergosono, Kendungkandang, Kota Malang

\begin{tabular}{|c|c|c|c|c|c|c|c|c|c|}
\hline \multirow{3}{*}{\multicolumn{2}{|c|}{$\begin{array}{c}\text { Hubungan antar } \\
\text { variabel }\end{array}$}} & \multicolumn{6}{|c|}{ Status Gizi Anak } & \multirow{2}{*}{\multicolumn{2}{|c|}{ Total }} \\
\hline & & \multicolumn{2}{|c|}{ Kurang } & \multicolumn{2}{|c|}{ Baik } & \multicolumn{2}{|c|}{ Lebih } & & \\
\hline & & $\mathrm{F}$ & $\begin{array}{c}(\% \\
)\end{array}$ & $\mathrm{f}$ & $(\%)$ & f & $\begin{array}{c}(\% \\
)\end{array}$ & f & (\%) \\
\hline \multirow{3}{*}{$\begin{array}{c}\text { Perila } \\
\text { ku } \\
\text { orang } \\
\text { tua }\end{array}$} & Baik & 1 & $\begin{array}{l}1, \\
7\end{array}$ & $\begin{array}{l}1 \\
6\end{array}$ & 26,7 & 1 & 1,7 & 18 & $\begin{array}{c}30, \\
0\end{array}$ \\
\hline & $\begin{array}{c}\text { Cuku } \\
\text { p }\end{array}$ & 2 & $\begin{array}{l}3, \\
3\end{array}$ & $\begin{array}{l}3 \\
5\end{array}$ & 58,3 & 2 & 3,3 & 39 & $\begin{array}{c}65, \\
0\end{array}$ \\
\hline & $\begin{array}{c}\text { Kuran } \\
\mathrm{g}\end{array}$ & 1 & $\begin{array}{l}1, \\
7\end{array}$ & 1 & 1,7 & 1 & 1,7 & 3 & 5,0 \\
\hline \multicolumn{2}{|c|}{ Total } & 4 & $\begin{array}{l}6, \\
7\end{array}$ & $\begin{array}{l}5 \\
2\end{array}$ & 86,7 & 4 & 6,7 & 60 & 100 \\
\hline
\end{tabular}

Berdasarkan Tabel 3. didapatkan dari $39(65,0 \%)$ orang tua yang memiliki perilaku cukup dalam pemilihan makanan bergizi menyebabkan sebanyak 35 (58,3\%) anak memiliki status gizi baik, hal ini dapat di artikan bahwa orang tua yang memiliki perilaku cukup dalam pemilihan makanan bergizi mampu meningkatkan status gizi anak menjadi baik atau sesuai.

Tabel 4. Analisis Data Hubungan Perilaku Orang Tua Dalam Pemilihan Makanan Bergizi Dengan Status Gizi Pada Anak Usia Pra Sekolah di TK ABA 06 Mergosono, Kendungkandang, Kota Malang

Perilaku Orang Tua Dalam Pemilihan

Makanan Bergizi (X)

(0, 0000

Status Gizi Pada Anak Usia Pra Sekolah (Y)

Berdasarkan Tabel 4. membuktikan hasil analisis uji spearman rank didapatkan nilai $p=(0,000)<(0,050)$ sehingga $\mathrm{H}_{1}$ diterima, artinya ada hubungan perilaku orang tua dalam pemilihan makanan bergizi dengan status gizi pada anak usia pra sekolah di TK ABA 06 Mergosono, Kendungkandang, Kota Malang, sedangkan nilai $r=0,700$ membuktikan bahwa terdapat hubungan positif yang kuat antara perilaku orang tua dalam pemilihan makanan bergizi dengan status gizi pada anak usia pra sekolah, dimana perilaku yang cukup dalam pemilihan makanan bergizi mendukung status gizi pada anak usia pra sekolah menjadi baik.

\section{PEMBAHASAN}

\section{Perilaku Orang Tua Dalam Pemilihan Makanan Bergizi}

Perilaku pemilihan makanan merupakan semua kegiatan atau aktivitas seseorang baik baik yang dapat diamati langsung maupun yang tidak dapat diamati. Perilaku pemilihan makanan meliputi dari pengetahuan, sikap, dan tindakan memilih makanan. Pengetahuan pemilihan makanan adalah kepandaian makanan yang disesuaikan dengan kebutuhan zat gizi dan kepandaian dalam memilih makanan yang sehat. Menurut (Nurohma Hestiani, 2014).

Berdasarkan tabel 3. membuktikan bahwa sebagian besar $39(65,0 \%)$ orang tua memiliki perilaku cukup dalam pemilihan makanan bergizi pada anak usia pra sekolah di TK ABA 06 Mergosono Kota Malang. Perilaku orang tua dalam pemilihan makanan bergizi seperti hati-hati dalam membeli jenis jajanan yang anak makan, mengetahui bentuk jajanan sehat melalui warna tidak mencolok dan tidak berbau tajam, serta melihat tanggal kadarluarsa sebelum membeli makanan. Perilaku orang tua dalam pemilihan makanan bergizi untuk mandukung tumbuh kembang anaknya meliputi memilih jenis jajanan yang anak makan, memberikan makanan bergizi dan sehat kepada anak. Menurut (Nurohma, 2014). 
Perilaku orang tua dalam pemilihan makanan bergizi merupakan tindakan orang tua untuk memberikan pangan bergizi kepada anak. Faktor-faktor yang mempengaruhi orang tua memiliki perilaku cukup dalam pemilihan makanan bergizi pada anak usia pra sekolah yaitu pengetahun, pendidikan, pekerjaan, pendapatan, sikap dan dukungan. Pengetahuan cukup diketahui dari sebagian besar responden berpendidikan SMA sehingga selalu masak setiap hari untuk memenuhi konsumsi pangan anak, pekerjaan sebagai swasta sehingga memiliki pendapatan yang cukup untuk memenuhi kebutuhan pangan anak, hal ini akan mendukung delam meningkatkan status gizi anak. Sesuai pendapat Maesarah dkk (2015) membuktikan bahwa pengetahuan orang tua yang cukup terhadap status gizi balita, karena mengetahui jenis-jenis makanan dan minuman apa saja yang bergizi untuk anak dan keluarganya, sehingga mendukung perilaku konsumsi pangan sehat. Berdasarkan hasil penelitian dapat dipahami bahwa orang tua yang memiliki perilaku cukup dalam pemilihan makanan bergizi pada anak usia pra sekolah seperti mengetahui kandungan gizi dalam makanan yang diberikan kepada anak, mengetahui jumlah makanan yang cukup untuk dikonsumsi anak, mengetahui jenis jajanan yang tidak sehat seperti warna mencolok, berbau tajam dan penyimpanan di tempat terbuka, memberikan makanan beragam saat makan seperti lauk-pauk, sayur, tahu/tempe, buah dan susu untuk mendukung tumbuh kembang anak, memilih jajanan yang dibungkus rapi dan bersih untuk diberikan kepada anaknya, mencuci bahan makanan sebelum memasaknya, serta membatasi anaknya mengkonsumsi makana yang manis seperi permen atau gula-gula.

\section{Status Gizi Pada Anak Usia Pra Sekolah}

\begin{tabular}{lcrr}
\multicolumn{4}{c}{ Status gizi adalah suatu keadaan } \\
tubuh yang di akibatkan & oleh \\
keseimbangan antara asupan & dan
\end{tabular} penggunaan zat gizi. Jika tubuh memperoleh cukup zat gizi dan digunakan secara efesian akan tercapai status gizi optimal yang memungkinkan pertumbuhan fisik, perkembangan otak, kemampuan kerza otak, dan kesehatan secara umum pada tingkat tinggi mungkin. Asupan makanan anak tergantung pada konsumsi makanan dalam keluarga. Konsumsi makanan dalam keluarga diperoleh oleh jumlah dan jenis panganan, pemasakan, kebiasan makan secara individu, pendapatan, agama, adat istiadat, dan pendidikan keluarga yang terkait. Makin bertambah usia anak maka makin makin bertambah pula kebutuhan akan zat gizi (Adriani, 2013).

Berdasarkan tabel 4. membuktikan hampir seluruhnya $52(86,7 \%)$ anak usia pra sekolah memiliki status gizi baik di TK ABA 06 Mergosono, Kendungkandang, Kota Malang. Status gizi baik pada anak usia pra sekolah seperti memiliki tinggi badan dan berat badan seimbang sehingga fisik terlihat sesuai, tidak kurus dan tidak gemuk. Menurut (Adriani \& Wirjatmadi 2012). Status gizi merupakan keadaan tubuh seimbang yang disebabkan kecukupan kebutuhan nutrisi dalam tubuh sehingga mengaktibatkan perubahan dalam bentuk ukuran fisik anak menjadi besar, tinggi dan sehat dari sebelumnya yang diukur menggunakan standar tabel Antropometri (Menurut Hriyani 2012). Faktor- faktor yang mempengaruhi status gizi yaitu asupan energi, asupan protein, tingkat konsumsi makanan, pendidikan, pengetahuan gizi ibu, pendapatan orang tua dan pola asuh orang tua. Anak yang memiliki status gizi baik dalam penelitian ini didukung oleh faktor pendidikan dan perilaku orang tua. Faktor pendidikan seperti ibu mengetahui jenis-jenis makanan yang sehat di konsumsi anak sehingga selalu memberi makanan yang di buat 
sendiri kepada anaknya. Faktor perilaku seperti ibu mengetahui makanan yang disukai anak dan mencukupi kebutuhan makanan anak. Sesuai penelitian (Sa'diya 2015). Menjelaskan anak yang memiliki status gizi baik didukung oleh perilaku ibu cukup dalam pemberian pola makan sehat. Anak usia pra sekolah memiliki status gizi baik dikarenakan memiliki perilaku cukup dalam pemilihan makanan bergizi, dimana memberikan perhatian terhadap kebutuhan pangan anak. Berdasarkan hasil penelitian didapatkan sebagian kecil $4(6,7 \%)$ anak memiliki status gizi lebih karena tidak adanya pengontrolan asupan makanan yang di konsumsi anak seperti mengkonsumsi gorengan atau makanan instan, membiarkan anak membeli jajanan sendiri dan tidak memeriksa bantuk jajanan yang anak konsumsi. Anak yang memiliki status gizi lebih diketahui dari fisik anak kegemukan hal ini akan menghambat anak melakukan aktivitas bermain sehingga mengganggu proses tumbuh kembang anak. Anak yang memiliki berat badan lebih didasarkan tidak adanya pengontrolan makanan yang dikonsumsi dimana pengawasan orang tua rendah. Sedangkan sebagian kecil 4 (6,7\%) anak memiliki status gizi kurang karena beberapa anak memiliki nafsu makan rendah karena makanan yang diberikan tidak sesuai selera anak.

\section{Hubungan Perilaku Orang Tua Dalam Pemilihan Makanan Bergizi Dengan Status Gizi Pada Anak Usia Pra Sekolah}

Perilaku yang paling sangat sering dilakukan orang tua adalah memberikan contoh yang sehat. Lima tahun pertama anak merupakan perilaku makan yang penting sebagai dasarpola makan yang akan datang. Peran orang tua sangat penting dalam pengalaman makan anak karena pengalaman ini akan berkaitan dengan dengan perilaku makan anak dan status berat badan. Perilaku orang tua dalam mengontrol perilaku makan anak berhubungan signifikat secara positif dengan status gizi anak pada kondisi anak kurus, normal, ataupun gemuk. Semakin sering orang tua membiarkan anak mengatur dan pemilihan makanan sendiri makan semakin tinggi status gizi anak. Kontrol makanan anak merupakan praktik pemberian makan yang negatif karena orang tua membiarkan anak mengatur sendiri pilihan makanan yang mempengaruhi sebagai banyak anak makan-makanan yang sehat. Perilaku orang tua dalam pemberian makan pada anak berdasarkan comprehensive feeding practices questionnaire (CFPQ) berhubungan dengan status gizi anak kecuali perilaku membatasi asupan makanan untuk kesehatan. Orang tua diharapkan menghindari perilaku pemberian makanan dengan menjanjikan hadiah atau untuk mengantur emosi anak dan memberikan tekanan pada saat anak makan. Lingkungan positif sangat mendorang anak untuk makan sangatlah penting bagi perkembangan fisik, mental, dan sosial (Ni Luh Agustini Purnama, Lely Lusmilasari, 2015).

Berdasarkan tabel 6. membuktikan hasil analisis uji spearman rank didapatkan nilai $p=(0,000)<(0,050)$ sehingga $\mathrm{H}_{1}$ diterima, artinya ada hubungan perilaku orang tua dalam pemilihan makanan bergizi dengan status gizi pada anak usia pra sekolah di TK ABA 06 Mergosono, Kendungkandang, Kota Malang, sedangkan nilai $r=0,700$ membuktikan bahwa terdapat hubungan positif yang kuat antara perilaku orang tua dalam pemilihan makanan bergizi dengan status gizi pada anak usia pra sekolah. Hal tersebut sesuai dengan hasil tabulasi silang didapatkan dari $39(65,0 \%)$ orang tua yang memiliki perilaku cukup dalam pemilihan makanan bergizi menyebabkan sebanyak $35(58,3 \%)$ anak memiliki status gizi baik. Berdasarkan hasil penelitian dapat dipahami bahwa perilaku orang tua yang cukup dalam pemilihan makanan bergizi 
mendukung status gizi pada anak usia pra sekolah menjadi baik. Perilaku orang tua dengan memberikan makanan bergizi, menyiapkan anak untuk sarapan pagi, memberikan makanan bervariasi sehingga anak gemar makan, memberikan makanan yang diolah sendiri sehingga mengetahui kebersihan makanan, tidak memberikan makanan instan dan tinggi lemak, serta orang tua memberikan makanan yang segar kepada anaknya. Perilaku orang tua yang cukup akan mencukupi kebutuhan makanan anak untuk mendukung proses tumbuh kembang dan status gizinya. Hasil penelitian ini sepaham dengan penelitian yang dilakukan oleh Chasandra (2014) membuktikan bahwa orang tua yang memiliki perilaku cukup dalam pemenuhan pangan anak akan meningkatkan status gizi menjadi baik, hal ini didukung oleh penghasilan keluarga dan pengetahuan ibu. Perilaku orang tua yang cukup dalam mengontrol perilaku makan anak berhubungan signifikat secara positif dengan status gizi anak manjadi baik. (Menurut Purnama \& Lusmilasari, 2015). Menjelaksan semakin sering orang tua mengatur dan pemilihan makanan untuk anaknya maka semakin tinggi status gizi anak.

\section{KESIMPULAN}

Penelitian tentang hubungan perilaku orang tua dalam pemilihan makanan bergizi dengan status gizi pada anak usia pra sekolah di TK ABA 06 Mergosono, Kendungkandang, Kota Malang, menyimpulkan bahwa:

Sebagian besar $39(65,0 \%)$ orang tua memiliki perilaku cukup dalam pemilihan makanan bergizi pada anak usia pra sekolah di TK ABA 06 Mergosono

Hampir seluruhnya $52 \quad(86,7 \%)$ anak usia pra sekolah memiliki status gizi baik di TK ABA 06 Mergosono, Kendungkandang, Kota malang.

Ada hubungan perilaku orang tua dalam pemilihan makanan bergizi dengan status gizi pada anak usia pra sekolah di TK ABA 06 Mergosono, Kendungkandang, Kota Malang didapatkan hubungan positif yang kuat antara perilaku orang tua dalam pemilihan makanan bergizi dengan status gizi pada

anak usia pra sekolah.

\section{DAFTAR RUJUKAN}

Adisasmito, wiku. (2010). Sistem Kesehatan. Jakarta: PT Raja Grafindo Persada

Adriani, M., \& Wirjatmadi, B. (2012). Peranan Gizi Dalam Siklus Kehidupan (2012th ed.). Jakarta: kencana pernada media group

Adriani, M dan Wirjatmadi, B. 2013. Peranan Gizi Dalam Siklus Kehidupan. Jakarta : Kencan Prenada Media Group

Afriani, L.H.. (2013). Teknologi Pengawetan Pangan (Ed. Revisi). Bandung : Alfabeta

Alimul Hidayat A.A., (2010). Metode Penelitian Kesehatan Paradigma Kualitatif. Jakarta : Heath Books

Anak, N., \& Yayasan, D. I. (2014). FaktorFaktor yang Berhubungan dengan Perilaku Ibu dalam Memenuhi Kebutuhan Nutrisi Anak di Yayasan AlFatah Serang. UIN SYarif Hidayatullah

Adriani, Wirjatmadi, B. (2012). Pengantar Gizi Masyarakat. Jakarta: Kencana Prenada Media Group Arisman. 2010. Gizi Dalam Kehidupan. Jakarta : Penerbit Buku Kedokteran EGC

Arikunto, S. 2015. Prosedur Penelitian. Jakarta: Rineka Cipta.I 
Budi. S dan \& yanti. Dwi A (2010). Menu sehat alami untuk balita dan balita. Jakarta : Agro Media Pustakai

Cobham A, Garde M, Crosby L, 2013. Global Stunting Reduction Target: Focus On

Dahlan. 2014. Statistik Untuk Kedokteran Dan Kesehatan Edisi 6. Jakarta: Salmba Medika

Detha Errene Chashandra, N. I. T. N. (2014). Hubungan Pola Asuh Ibu Dengan Status Gizi Anak Pra Sekolah (>3-5 Tahun). Journal Kesehatan Andalas, X(2), 171-177

Hariyani, S. 2012. Gizi Untuk Kesehatan Ibu dan Anak. Yoggyakarta : Graha Ilmu

http://www.depkes.go.id/article/view/1 8110200003/potret-sehat-indonesiadari-riskesdes2018.html Tanggal 07 mei 2019

Hidayat. 2005. Pengantar ilmu keperawatan anak, Edisi 2. Salemba Medika : Jakarta.

Khodijah, Nyayu. Psikologi Pendidikan. 2014 Jakarta: Rajawali Pers

Lutfi. Fauji Ridwan. Faktor-faktor yang berhubungan Dengan Perilaku Sadar Gizi Pada Keluarga Balita di Kelurahan Karang panimbal kecamatan purwarji Kota Banjar. Program Studi Kesehatan Masyarakat UIN Syarif Hidayatullah Jakarta. 2010
Maulana, Hari, d.j, 2010, Promosi Kesehatan Jakarta : EGC

Ni Luh Agustini Purnama, Lely Lusmilasari, M. J. (2015). Perilaku Orang Tua dalam Pemberian Makan dan Status Gizi Anak Usia 2-5 Tahun. Jurnal Gizi Klinik Indonesia, 11(03), 97-104

Notoadmodj, Soekidja. Promosi Kesehatan Teori dan Aplikasi. Jakarta: Rineka Cipta. 2010

Notoatmodjo, Soekidjo. Promosi Kesehatan Dan Perilaku Kesehatan. Jakarta: Rineka Cipta 2012. h. 131-207

Nursalam. (2011). Konsep dan Penerapan Metodologi Penelitian Ilmu Keperawatan. Jakarta: Selembang Medika

Shan, X. 2010. Influence of Parents' Childfeeding Practices on Child's Weight Status among Chinese Adolescents in Bajing, China (Doctoral dissertation, South Illinois University Carbondale). Diakses 13 mei 2015 ehs.siu.edu/herl_commom/documrnts/d issertation/dissertation/joy-shan-

dissertation.pdfUnicef Indonesia. 2013 Rinkasan Kajian Gizi Ibu dan Anak, Oktober 2012 Akses www.unicef.org Tanggal 16 Desember 2013

Sutomo, B dan Anggraini, DY. 2010. Menu Sehat Alami Untuk Balita \& Balita. Jakarta : PT. Agromedia Pustaka 